\title{
Effects of the Infrared Lamp Illumination during the Process of Muscle Fatigue in Rats
}

\author{
Andréia Zarzour Abou-Hala ${ }^{1}$, Daniella Galvão Barbosa ${ }^{2}$, Rodrigo Labat Marcos $^{3}$, Cristina \\ Pacheco-Soares ${ }^{1}$ and Newton Soares da Silva ${ }^{1 *}$ \\ ${ }^{1}$ Laboratório de Biologia Celular e Tecidual; ${ }^{2}$ Laboratório de Fluorescência; ${ }^{3}$ Laboratório de Fisiologia e \\ Farmacodinâmica; Instituto de Pesquisa e Desenvolvimento; Universidade do Vale do Paraíba - UNIVAP; Av. \\ Shishima Hifumi, 2911; nsoares@ univap.br; 12244-000; São José dos Campos - SP - Brasil
}

\begin{abstract}
In this study the effects of infrared lamp illumination during the muscle fatigue process was studied. Three different groups $(n=5)$ were used: one control group and two treated (Infrared Lamp 780$1400 \mathrm{~nm}$ ), with the energy densities of 0.5 and $1.0 \mathrm{~J} / \mathrm{cm}^{2}$ and time of illumination of 300 seconds. The treated animals were illuminated in one point directly in the tibialis muscle, after the first tetanic contraction out of six, with an interval between each tetany. The results were registered in an electrophysiograph and the intensity of the force of contraction in grams was analysed. It was observed that the control group presented a reduction in the intensity of the force of contraction, while the treated group managed to maintain it, which was clearly evident in the energy density of $0.5 \mathrm{~J} / \mathrm{cm}^{2}$. It was concluded that the use of the infrared lamp illumination was efficient concerning resistance to muscle fatigue.
\end{abstract}

Key words: Muscle fatigue; infrared illumination; muscle tension; tetany

\section{INTRODUCTION}

Muscle fatigue can be defined as the group of manifestations produced by work or prolonged exercise. The consequence will be the reduction in maintaining or continuing the expected result (Rossi, 1999; Schwid, 2002). Muscle fatigue may alter muscle functioning due to the exhaustion of mediators at several levels, which can establish a muscular unbalance, making easier the appearance of lesions (Fitts, 1996). Possible causes of the muscle fatigue can be failure of the motor nerve, the neuromuscular junction, the central nervous system and also the contractile mechanism, in which fatigue takes place due to the depletion of the adenosine triphosphate and muscular glycogen stock and the large amount of lactic acid (Fox et al., 1991; Thomas et al., 2003). Muscle fatigue may be the result of impairments at any of a number of sites within the neuromuscular system, which manifests as a decline in the maximum force-generating capacity of the muscle (Fulco at al., 2001; Allman and Rice, 2002).

The skeletal muscle, when exposed to intense and continuous effort, tends to lose its contractile capacity. This occurs because during the contraction, the intramuscular pressure exceeds the blood pressure, obliterating small nutrition vessels and the oxygen flow as well. The muscle cells obtain energy through the anaerobic glycolysis in

author for correspondence 
which the metabolic result is the lactic acid. Clinically, this phenomenon is interpreted as contractures and reduction of the muscular functional capacity, due to decrease in the peak tension and power (Fitts, 1996).

The use of infrared (IR) radiation in the treatment of a variety of medical conditions has been studied for a long time. The IR radiation is applied in the inner part of the electromagnetic spectrum which generates heat when absorbed by matter (Kitchen and Partridge, 1991; Gul and O'Sullivan, 2005). According to Moss et al. (1989), many sources which emit either visible or ultraviolet radiation will also emit IR and this IR radiation have different refractive indices and different reflection, transmission and scattering characteristics, depending on the wavelength of the light. Infrared radiation in the IR-B (medium infrared: $1.4-3 \mu \mathrm{m}$ ) and IR-C (long infrared: $3 \mu \mathrm{m}-1 \mathrm{~mm}$ ) ranges is absorbed in the top layers of the skin. The shorterwavelength IR-A radiation $(780-1400 \eta \mathrm{m})$ has a greater penetrating power. The IR lamp, a noncoherent irradiation, has a wavelength spectrum with a pronounced peak approximately $1000 \eta \mathrm{m}$ in the deep-penetrating IR-A range. All of these patterns are quite important when measuring IR radiations but only the reflection and absorption are extremely meaningful biologically and clinically since they have been considered effects of IR radiation on tissues.

The investigation into the effect of the IR lamp illumination during the process of muscle fatigue in tibialis anterior muscle of rats was the main goal of this study.

\section{MATERIALS AND METHODS}

In this study the ethical principles of animal experimentation was applied in conformity to COBEA (Brazilian School of Experimentation Animal), having been approved by the Committee of Ethics in Research of UniVap, Protocol $n^{\circ}$ L007/2003/CEP. Fifteen (15) male Wistar rats were used, weighing between 250 and $300 \mathrm{~g}$. During the experiment, the animals were housed under standard conditions in cages, five animals per cage and kept under constant conditions of temperature $\left(22 \pm 2^{\circ} \mathrm{C}\right)$ with a 12 -h light/12-h dark cycle. The rats were fed with ad libitum and supplied with drinking water.

All surgical procedures were performed under aseptic conditions. Each animal was pre- anesthetized with Butorfanol (Torbugesic $\AA$ ), in the dose of $2 \mathrm{mg} / \mathrm{Kg}$ via intramuscular (Flecknell, 1996). After 15 minutes, the rat was sedated with chloral hydrate (i.p.), in the dose of $420 \mathrm{mg} / \mathrm{kg}$ in a $10 \%$ solution (Almaguer-Melián et al., 1999) and placed on a surgical table where it was carried through the withdrawal of the skin and dissecation of the muscle previous tibial with the purpose to isolate the nerve fibular deep (responsible for the stimulation of the muscle) isolated the nerve, in the region of the insertion next to the plantar to metatarsus region, the muscle (through the tendon) was connected to an isometric transducer ( $\mathrm{Ugo}$ Basile ${ }^{\circledR}$; Vareze, Italy) that it transforms the data of muscle tension into electric signals transmitted to the electrophysiograph and the nerve connected to a bipolar electrode, on to the eletrostimulator, for indirect inervation of the muscle.

The muscle was exposed to a constant tension of $10 \mathrm{~g}$. The muscle was stimulated indirectly by pulses of $7 \mathrm{~V}, 0.2 \mathrm{~Hz}$ for 2 miliseconds. The muscle and tetanics contractions in response to the indirect stimulations were registered in a physiograph (GEMINI 7070 of UGO BASILE®) through the isometric transducer for approximately 60 minutes. To stimulate the tetanic contraction, the frequency was raised to $60 \mathrm{~Hz}$, every 10 minutes, out of six contractions (Marcos, 2002; Lopes-Martins et al., 2006). During the whole experiment, the muscle was dampened with a sterile saline solution $(0.9 \%)$ to prevent drying.

The muscle fatigue was determined by the incapacity to keep the muscle contraction. Therefore, there would be a decline of the amplitude in 50\% maximum contraction muscle recorded, to prevent the death of the tissue because of the tetanic contraction.

The animals were divided in three groups, which were:

1) Control group: not radiated, with stimulation of 6 tetanic contractions;

2) Infrared Lamp Illumination, energy density of $0.5 \mathrm{~J} / \mathrm{cm}^{2}$

3) Infrared Lamp Illumination, energy density of $1.0 \mathrm{~J} / \mathrm{cm}^{2}$.

A PHILIPS $^{\circledR}$ lamp - Infrared 780-1400nm (Fig. 1) was used. The treated animals were illuminated in one point after the stimulation of the first tetanic contraction, directly in the tibialis muscle exposed at that moment. The patterns of each protocol are indicated in table 1.

At the end of each experiment the animals were killed with excessive intracardiac dose of Sodium 
Thiopental (Thiopentax ${ }^{\circledR}$ ), 60mg/kg (Thurmon, 1999). The data obtained were analyzed statistically by the test of variance analysis to $5 \%$ of probability (ANOVA). The average and the standard error (s.e.) of the average was calculated and the difference among the data of the control group and irradiated was determined by the Tukey test. Significant values were considered statistically with $\mathrm{p}<0.05, \mathrm{p}<0.01$ and $\mathrm{p}<0.001$.

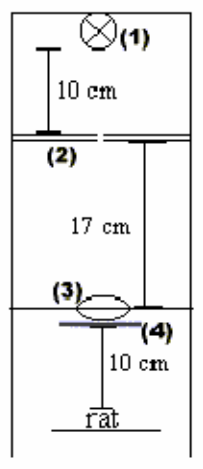

Figure 1 - Esquematic drawing of the assembly of the box: (1) Infrared Lamp (Philips ${ }^{\circledR}$ ), (2) Wooden Pinhole (Ø 5mm), (3) Lens (CSR® - Ø 50mm 6x) and (4) Filters

Table 1 - Protocol of IR irradiation

\begin{tabular}{lcc}
\hline Parameters of irradiation & Values & Values \\
\hline Energy density & $0.5 \mathrm{~J} / \mathrm{cm}^{2}$ & $1 \mathrm{~J} / \mathrm{cm}^{2}$ \\
Potency & $0.5 \mathrm{~mW}$ & $1 \mathrm{~mW}$ \\
Wavelength & $780-1400 \mathrm{~nm}$ & $780-1400 \mathrm{~nm}$ \\
Area & $0.3 \mathrm{~cm}^{2}$ & $0.3 \mathrm{~cm}^{2}$ \\
Time & 300 seconds & 300 seconds \\
\hline
\end{tabular}

\section{RESULTS}

The results of the intensity of the force of contraction measured in each electric stimulation, after tetany were analyzed (Fig. 2). It was observed that in the control group a decrease in the muscle tension (intensity of the muscle force) occurred during the tetanic contractions and this reduction was even better observed by a fall after the first tetanic contraction.
In the treated group with energy density of $0.5 \mathrm{~J} / \mathrm{cm}^{2}$, a significant fall was not observed. In the treated group with energy density of $1.0 \mathrm{~J} / \mathrm{cm}^{2}$, a significant fall was observed after the third tetanic contraction, being more highlighted from the fourth contraction on.

In the animals of the control group, the most significant fall of $26.7 \%$ was observed. The treated group with $0.5 \mathrm{~J} / \mathrm{cm}^{2}$ presented a fall of $6.0 \%$ (lesser fall) and the treated group of $1.0 \mathrm{~J} / \mathrm{cm}^{2}$ presented a fall of $14.5 \%$. 


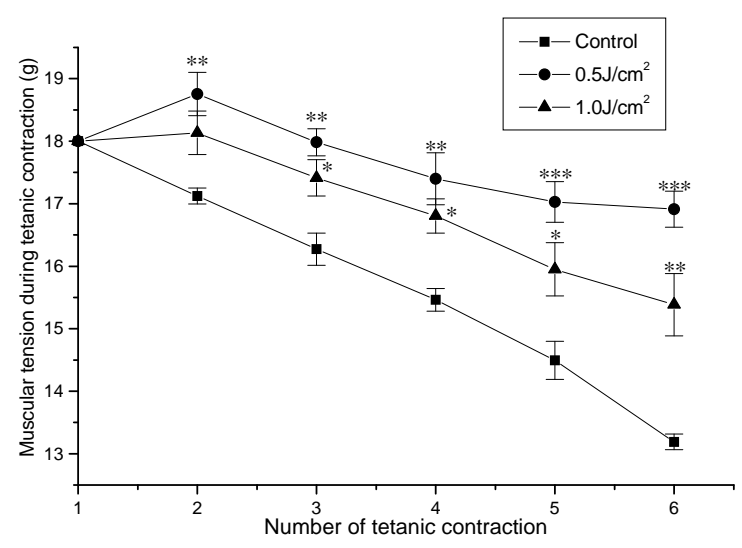

\begin{tabular}{ccccccc}
\hline Group & $\mathbf{1}$ & $\mathbf{2}$ & $\mathbf{3}$ & $\mathbf{4}$ & $\mathbf{5}$ & $\mathbf{6}$ \\
\hline Control & 18.4 & $17.1 \pm 0.1278$ & $16.3 \pm 0.2556$ & $15.5 \pm 0.1826$ & $14.5 \pm 0.3034$ & $13.2 \pm 0.1258$ \\
$0.5 \mathrm{~J} / \mathrm{cm}^{2}$ & 18.4 & $18.8 \pm 0.3452$ & $18.0 \pm 0.2154$ & $17.4 \pm 0.4169$ & $17.0 \pm 0.3262$ & $16.9 \pm 0.2880$ \\
$1.0 \mathrm{~J} / \mathrm{cm}^{2}$ & 18.4 & $18.1 \pm 0.3475$ & $17.4 \pm 0.2909$ & $16.8 \pm 0.2733$ & $15.9 \pm 0.4264$ & $15.4 \pm 0.4992$ \\
\hline
\end{tabular}

Figure 2 - Intensity of the muscle contraction force by tetanic contractions (mean \pm se) $(* \mathrm{p}<0.05$, $* * \mathrm{p}<0.01$ and $* * * \mathrm{p}<0.001)$

\section{DISCUSSION}

This study has investigated, through the IR lamp illumination, the reduction of the muscle fatigue in tibialis anterior muscle of rats after stimulation of tetanic contractions by indirect electrical stimulus. By using the IR lamp illumination with energy densities of 0.5 and $1.0 \mathrm{~J} / \mathrm{cm}^{2}$, it was possible to observe a reduction in the intensity of the force of contraction of 6.0 and $14.5 \%$, respectively; both being less than the control group (26.7\%). High levels of certain metabolites in the blood, due to the increased metabolic activity arising from the high temperatures, have a direct effect on vessel walls, stimulating vasodilation (Ward, 1986; Wells et al., 1988; Ganong, 1989). According to Massuda et al. (2005), the high rate of metabolism due to increased body temperature and increased blood flow, decreased subjective symptoms, resulting in increased energy scores, hence promoting a better resistance related to muscular fatigue.

Although has been proved that the use of the IR lamp illumination improve the resistance, further studies should be done in order to determine such effects, clearly showing that the treatment with the IR lamp illumination was efficient.

\section{CONCLUSION}

It could be concluded that the use of the IR lamp illumination with energy density of $0.5 \mathrm{~J} / \mathrm{cm}^{2}$ promoted more resistance to the muscle fatigue.

\section{ACKNOWLEDGEMENTS}

We are grateful to Chaker Nayef Abou Hala and Ana Paula Marques de Mendonça Lopes for technical assistance, and Renato Amaro Zângaro, $\mathrm{PhD}$ (Laboratório de Fluorescência).

\section{RESUMO}

Neste estudo investigamos o efeito da irradiação da lâmpada infravermelha durante o processo de fadiga muscular. Foram utilizados 3 grupos diferentes $(n=5)$, sendo 1 grupo controle e 2 irradiados (Lâmpada de Infravermelho 780$1400 \mathrm{~nm}$ ), nas densidades de energia 0,5 e $1,0 \mathrm{~J} / \mathrm{cm}^{2}$ e tempo de irradiação 300 segundos. Os animais irradiados receberam 1 irradiação em 1 ponto, diretamente no músculo tibial, após a primeira contração tetânica de um total de seis, com um intervalo entre cada tetania. Os resultados foram registrados em eletrofisiógrafo e analisado a intensidade da força de contração em gramas. Foi observado que o grupo controle apresentou uma 
redução na intensidade da força de contração, já os grupos irradiados conseguiram mantê-la, sendo mais evidente quando irradiado com densidade de energia (DE) de $0,5 \mathrm{~J} / \mathrm{cm}^{2}$. Conclui-se que a utilização da irradiação da lâmpada infravermelha é eficaz na resistência a fadiga muscular.

\section{REFERENCES}

Allman, B. L. and Rice, C. L. (2002), Neuromuscular fatigue and aging: central and peripheral factors. Muscle Nerve, 25, 785-796

Almaguer-melián, W. et al. (1999), Estudio comparativo de la lesión de fimbria- fórnix por aspiración y transección. Revista de Neurología, 29(8), 704-709

Fitts, R. H. (1996), Muscle fatigue: the cellular aspects. The American Journal of Sports Medicine, 24(6), 9-13

Flecknell, P. (1996), Laboratory Animal Anesthesia. 2nd. ed. Academia Press, 274p.

Fox, E. L.; Bowers, R. W. and Foss, M. L. (1991), Bases fisiológicas da educação física e dos desportos. 4. ed. Rio de Janeiro: Guanabara Koogan, 518p

Fulco C. S. (2001) Gender alters impact of hypobaric hypoxia on adductor pollicis muscle performance. $J$ Appl Physiol,91, 100-108

Ganong, W. F. (1989), Review of Medical Physiology. 14th. ed. California: Lange Medical Publications, 665p

Gul, A. and O'Sullivan, S. T. (2005), Iatrogenic burns caused by infra red lamp after traditional acupuncture. Burns, 31, 1061-1062.

Kitchen, S. S. and Partridge, C. J. (1991), Infrared therapy. Physiotherapy, 77(4), 249-254

Lopes-Martins, R.L.; Marcos, R.L.; Leonardo, P.S.; Prianti Jr., A.C.; Muscará, M.N.; Aimbire, F.; Frigo, L.; Iversen, V.I. and Bjordal, J.M. (2006), The effect of low level laser irradiation (Ga-AI-As - 655nm) on skeletal muscle fatigue induced by electrical stimulation in rats. J Appl Physiol (in press) 20,130.

Marcos, R. L. (2002) Avaliação do efeito da irradiação laser AsGaAl (630-680nm) no modelo experimental de fadiga muscular por estimulação elétrica em ratos. 56f. Dissertação (Mestrado em Engenharia Biomédica) - Universidade do Vale do Paraíba, São José dos Campos, São Paulo, Brasil

Masuda, A. et al. (2005), The effects of repeated thermal therapy for two patients with chronic fatigue syndrome. Journal of Psychosomatic Research, 58, 383-387.

Moss, C. et al. (1989), Infra-red Radiation. Nonionising Radiation Protection. 2nd. ed., Geneva: WHO Regional Publications, European Series, n. 25

Rossi, L. and Tirapegui, J. (1999), Aspectos atuais sobre exercício físico, fadiga e nutrição. Revista Paulista de Educação Física, 13(1), 67-82

Schwid, S. R. et al. (2002), Fatigue in multiple sclerosis: Current understanding and future directions. J. Rehab. Research and Development, 39(2), 211-224

Thomas, C. K. et al. (2003), Fatigue of paralysed and control thenar muscles induced by variable or constant frequency stimulation. J Neurophysiology, 89, 2055-2064

Thurmon, J. C.; Tranquilli, W. J. and Benson, G. J. (1999), Essentials of Small Animal Anesthesia and Analgesia. Lippincott Williams and Wilkins, pp. 536-562

Ward, A. R. (1986), Electricity Fields and Waves in Therapy, Australia: Science Press

Wells, P. E.; Frampton, V. and Bowsher, D. (eds) (1988), Pain: Management and control in physiotherapy, London: Heinemann.

Received: November 12, 2004; Revised: August 12, 2005; Accepted: March 12, 2007. 
PÁGINA

EM

BRANCO 